\title{
The Effectiveness Of Qanun Aceh No. 6/2014 Of Jinayat Law In Order To Prevent Jinayah Khalwat In Law Territory Of Sabang Municipality
}

"Webby Adityta1"

\begin{tabular}{ll}
\multicolumn{2}{l}{ ARTICLE HISTORY } \\
\hline Received & $: 19$ March 2018; \\
Reviewed & $: 29$ April 2018; \\
Accepted & $: 30$ April 2018; \\
Published & $: 30$ April 2018.
\end{tabular}

\section{KEYWORDS}

Jinayat Law;Khalwat Fingers; Obstacles.

\section{CORRESPONDENSE}

${ }^{1}$ Mahasiswa, Jalan Yossudarso Gampong Cot $B a^{\prime}$ u Kecamatan Sukajaya Kota Saban, 23522, Indonesia.

E-Mail:webbyaditya.adit@yahoo.com

\section{A B S T R A C T}

Article 23 paragraph (1) of Aceh Islamic Criminal Law No 6 of 2014 tells about Indecency (Jinayat) law which regulates the criminal punishment for the perpetrator of jarimah khalwat. This article is expected can minimize the crime rate of the indecent (jinayah) behavior perpetrator. However, in fact the number of jarimah khalwat perpetrator increase steadily as what happened in Sabang Municipality law area. It proves that there were two legal issues, what is the causes of the ineffectiveness of the indecency (jinayat) law in minimizing the number of jinayat perpetrator in Sabang Municipality? This research was aimed to know the obstacle of the increasing jinayat khalwat issue which make jinayat law become ineffective in minimizing jinayat khalwat perpetrators in Sabang Municipality, and to know the efforts conducted by the Civil Service Police Unit, Sharia Policy, and Office of the District Prosecutor General of Sabang Municipality and to know the factor which causes the number of jinayah khalwat perpetrator in Sabang Municipality. The research method used in this research was empirical juridical empirical using case approach, historical approach, comparative approach, conceptual approach, and statute approach). The research result shown that there were 3 effectiveness obstacle factors of jinayat law in Sabang Municipality, the first obstacle of jinayat law is the bad regulation because the punishment is an alternative not a cumulative and for those who deal with the jinayat law is potentially punished with canning punishment in public, the application of jinayat law normatively is in contrary with the basis of personality and territoriality which causes this law contrary with the fair legal system (due process of law). The second factor which becomes the obstacle related to quality and quantity of the human resource of the law enforcement, law understanding and the number of personnel investigator of the Civil Service Police Unit and Sharia Police of Sabang Municipality was limited. The third factor, there is no special jinayah prison cell in the Civil Service Police Unit and Sharia Police of Sabang Municiplaity 


\section{Introduction}

Nowadays, Indonesia as a Law Country has been $\mathrm{n}$ a good progre related to law, by using a refined law with unity values not only respect the similarities but also the differences caused by tribe, religion or culture. As a result, the term of these differences has changed to diversity and resulted in value of speciality. Furthermore, in order to unite the diversity of this nation, it has beed defined as a united symbol which wellknown as Bhineka Tunggal Ika. The state recognition of this diversity has mentioned on article $18 \mathrm{~b}$ the constitution of Republic Indonesia ' 1945 which state:

(1) The state has admitted and respect the local government with the speciality which regulates based on law.

(2) The state has admitted and respect the united of customary law communities including their traditional rights as long as it still up date with the community development dan the principal of Republic Indonesia, which regulated by the law. ${ }^{1}$

Aceh Province which located on the western part of Indonesia, has a special value by implementin the Syariat Islam. This law has rooted from the past even before the independence of Indonesia. The evidence of this syariat could be found from the cultue of Acehneese community. Even the culture is more dominant than the syariat. The Islamic Syariat which understanding by the community not only from the law perspective, but also from other aspects for example education, economy (ownership and land used, water management for irrigation purpose, regulation of fishing, etc, government (at least on village stage), kind of social services, art, and culture, and sport. However, because of the limitation of this journal, then it will be focused on law and justice. $^{2}$

During reformation era, the demand of implementing of Syariat Islam in Aceh has

1 Kaelan. (2004). "Pendidikan Pancasila". Yogyakarta: Paradigma. P. 275.

2 Al Yasa Abubakar, "Sekilas Syariat Islam di Aceh". Dinas Syariat Islam Provinsi Aceh, P. 3.

3 Ibid, P. 5-6. grown rapidly. This demand has responsed by national parliament (DPR RI) which resulted in Act No. 44/ 1999 about the implementation of the speciality. It contains of regulation of Aceh speciality implementation that has been given in 1959. Next, along with DPR RO initiative, another act has been passed that is Act No. 18/2001 about special autonomy of Aceh as Nanggroe Aceh Darussalam Province. ${ }^{3}$ This time the consideration of this Act has related to special character of Acehneese people which is life perspective, social character and powerful Islamic culture which resulted in Aceh as a modal area in Indonesia independent history. 4

The mandate of Act No 18/2001, the central government should give a big authority to regulate the government for Aceh. This regulation then becomes an Act No. 11/ 2006 about The government of Aceh. By issuing this act, the syariat islam implementation has been stronger.

The special autonomy has bring some changes in law and justice where the religion justice has changed to Mahkamah Syari' ah as mentioned in article 25 Act 18/2001 ncluding the authority of Makhmah Syariat to adjudice Jinayah case. For this statement, article 15 Act no. 24/ 2004 also make it more strong which stated that Syariat Islam juctice $n$ Aceh is the special justice for religion justice and special justice in public justice. Beside it, Act No 16/2004 stated that attorney has an authority to judge the criminal case and send it to Mahkamah Syariah. ${ }^{5}$

After discussing the base law of the institution, then it will discuss about kind of criminal case (jinayah) which can be send to Mahkamah Syariah. From 2002 to 2004 there are 5 (five) qanuns (local regulations) which has been passed by Government of Nanggroe Aceh Darussalam and the local parliament (DPRA) about Jinayah.

4 Dinas Syariat Islam Nanggroe Aceh Darussalam,, Himpunan Undang-undang, Keputusan Presiden, Peraturan Daerah/Qanun, Instruksi Gubernur, dan Edaran Gubernur. (2005). Banda Aceh: CV.Hardyan. P.1

5. Op.Cit. P. 6. 
Furthermore, Qanun Jinayah has classified based on the action of the differences:

1. Qanun Aceh No. 11/ 2002 about the implementation of Syariat Islam in Aqidah, Ibadah and Syiar Islam;

2. Qanun Aceh No. 12/ 2003 about Khamar drinking and its kind;

3. Qanun Aceh No. 13/ 2003 about gambling (Maisir/ Perjudian);

4. Qanun Aceh No. 14/ 2003 about adultery (Khalwat/ Mesum);

5. Qanun Aceh No. 7/ 2004 about management of Zakat.

The justice insitution formation, regulations, and the punishment implementation is only the initiaal step which has to be followed by more important, well-planned and sustainable steps. As a result, the judgement of Mahkamah Syariah is a representative of community justice, ${ }^{6}$ However, sometimes, the reality is contradict with the hopes and followed by strong critical started from the case element that will be decided in every qanun, the punishment/ uqubat which contained of wip punishment and becomes new thing in criminal system of punishment in Indonesia and contradicted by the human right until the growth number of Jinayah actors. The main core is if the law officers is weak, the judgment of justice could not represent the justice of community needs. These issues has encourage the DPRA and the governor to revise the Jinayah qanun in order to answer the problems. It is expected to reduce the criminal actions among the community.

For a period of time, the new Qanun of Jinayah has passed, Qanun Aceh No. 6/2014 which contains of kind of Jinayah in one regulation.

Kind of Jinayah which regulated in Qanun No. $6 / 2014$ has stated under article 2 verse 3 as followed :

1. Khamar,

2. Maisir,

3. Khalwat,

4. Ikhtilath,

5. Zina,

6. Sexual Abusement (Pelecehan Seksual),

7. Rape (Pemerkosaan),
8. Qadzaf,

9. Liwath,

10. Musahaqah.

For those 10 kind of Jarimah above, the discussion of Jinayah Khalwat is very interesting to analyse, especially in Sabang Municipality based on the fact that since the implementation of Qanun No.6/2014 the Khalwat case in Sabang Municipality didn't reduce significantly. Moreover, based on the evidence from The State of Prosecutor's Office, the Khalwat case has increase. The next table reveals number of Jinayah Khalwat perpetrators in Sabang Municipalit from June 2015 to February 2017:

\section{Table I}

The State of Prosecutor's Office

Number of Jinayah Khalwat Perpetrators in Sabang Municipalty

\begin{tabular}{|c|c|l|}
\hline Year & Number of Perpetrators & \multicolumn{1}{|c|}{ Explanation } \\
\hline Jun-15 & 0 (Nol) people & Executed \\
\hline 2016 & 4 (Four) peoples & Executed \\
\hline Feb-17 & 20 (Twenty) peoples & 18 peoples has been executed \\
\hline Total & 24 (Twenty Four) peoples & \\
\hline
\end{tabular}

Based on the table, it reveals that since the implementation of Qanun No. 6/ 2014, from 2015 to early 2017 there is a significant increase of Khalwat perpetrators number with totala number is 24 peoples. It is very suprising because in new Qanun of Jinayah No. 6/ 2014, the punishment threat has increased and also the criminal threat has been added which means, the perpetrators not only faced the main uqubat tazir but also additional punishment of uqubat tazir.

The law effectiveness theory becomes an analysis tool which has been used to answer the contraints of why Jinayah Khalwat case in Sabang Municipality has increased. Furthermore, there are 5 (five) factors which become the indicators of law effectiveness, for example:

1. The law factor itself (Act);

2. The factor of law officer which means the stakeholder of the formation and implementation of law;

6 Ibid, P.8. 
3. The factor of facilities that support the law justice;

4. The factor of community, which means the environment of law implementation;

5. The factor of culture, as a creativity and tasty sense of human.7

\section{Method}

The research method that will be used is the empirical juridiction by using field data source as a primary data including the interview data with the stakeholders. The secondary data has collected from books, journals, Acts and internet. Some of approaches that will be used in this journal for example, case approach that is an approach by using special cases that has direct link with the research; historical approach used to find out the history of Jinayah Law in Aceh from the period of time to understand the phylosophy of Syariat Islam in Aceh (Qanun No.6 Tahun 2014 Tentang Hukum Jinayat) and the satae approach which used to search the regulations that could be condusive for Khalwat Jinayah implementation ${ }^{8}$.

\section{The Effectiveness Of Qanun Aceh No. 6/2014 Of Jinayat Law In Order To Prevent Jinayah Khalwat In Law Territory Of Sabang Municipality}

The implementation of Jinayat Law in Aceh comprehensively has been done since middle of 2015 until now, and the punishment implentation has anounced the Syariat Islam in Aceh. However, the nature of of Jinayat Law in Aceh is not using as a ceremony tool of Syariat Islam inauguration only, but also for another objective to reduce the criminal case and to build the awareness of community to form Islamiyah characteristic. It needs a long process for sure ${ }^{9}$ and also strong support from the stakeholders and community awareness for better future.

Jinayah law which becomes one of tools to form the Islamiyah Character in Aceh community not only become a social control tool but also a social

7 Soerjono Soekanto. (2008). "Faktor-Faktor yang Mempengaruhi Penegakan Hukum". Jakarta: PT. Raja Grafindo Persada P. 8.

8 Peter Mahmud Marzuki, "Penelitian Hukum". Jakarta: Kencana Prenada Media Grup. P.166.

$9 \quad$ Ibid, P. 337 engineering tool to develop a strong character of islamiyah. This mechnism is expected to implement optimally to create strong Aceh with islamic values because the basic of the formatiion is Al-Quran and $\mathrm{Al}$ hadist. For this statement, it has mentioned in Act No. 11/ 2006 about Jinayat Law under article 23 verse (1) ; Everyone who doing Jarimah Khalwat intentionally, will threated by U'qubat Ta'zir of 10 (ten) times of whip optimally or fine of 100 (hundred) gram of pure gold or jailed for 10 (ten) months maximal. This article considerate weak from punishment aspect point of view because the attorney have to choose one of kind of main uqubat.

The limitation of the attorney in this case has an effect into eradication process of Jinayah Khalwat perpetrators, as it is expected to give dterrent efect for the perpetrators but it seem hard to happen. ${ }^{10}$ The opinion stated by Yunadi S.H represent the weakness of Uqubat of Jinayat Law in Aceh. He stated that the implementation of Jinayah law in Aceh will nonoptimal because the implentation couldn't achieve none of the islamic criminal objectives such as revenge, prevention, the means of loss for the victims, and sin rebellation.

Another problem of Uqubat in Jinayah Law is the implementation og whip punishment for kids, this issue has contradicted with Act No. 35/ 2014 about Children Protection which mentioned that every children has their own right to live, growth and develop also has right to self protection from discrimination and abusement as statetd under the 1945 constitution. Moreover, the implementation of whip punishment in front of public area will give negative impact for their growth period because of the trauma effect that will be hard to be cured. This is the reflection of Jinayah Law regulation that put the problems children in unfair position in front of the law. ${ }^{11}$

10 Yunadi. (2017). "Ajun Fungsional Kejaksaan Negeri Kota Sabang" Wawancara 23 Agustus 2017.

11 Moh.din, Dosen Hukum Pidana Fakultas Hukum Unsyiah, Wawancara 15 Januari 2017. 
A good law is a representative of sense of justice, benefit, and the certainty of law, because this law has been formed to regulate public needs and also has its functioned to organise the life order of community.12 The way of law to maintain the public need by using the written rules has defined in Legality Principle as follow: Nulla poena sine lege which means no criminal without the criminal regulation based on the act, Nulla poena sine crimeartinya no criminal without the action itself, Nulla crimen sine poena legali which means no criminal without the criminal action based on the act, 13 In contrary there is a difference in Qanun Aceh No. 6/ 2014 about the Jinayah Law article 5 letter b and c:

b. Everyone who not a moslem who did Jarimah in Aceh together with the moslems and choosing to defeat his/her self to Jinayat Law voluntary;

c. Everyone who not a moslem who did the Jarimah in Aceh that not regulate under Kitab Undang-Undang Hukum Pidana (KUHP) or any criminal regulations outside the KUHP, but it rules in this Qanun;

The above article is seem to implement the personality principle which menas that kind of protection form for Indonesia citizen who did the criminal things in overseas because they didn't know the regulation of the criminal in that country, however, it seems unfair for the citizen if they will judge based on the foreign rules in that country philosophically. In practical, this principle is hard to protect the Indonesia citizen without the extradiction memorandum with the foreign country, the definition of the personality principle above didn't has correlation with Qanun Aceh No. 6/ 2014 about Hukum Jinayat Pasal 5 huruf $b$ dan $c$, as mentioned for subject of law, law position in personality principle has a goal to protect Indonesia citizen who didn't know about the foreign law meanwhile, in the article above a protection has given to non moslem to choose to defeat his/her self under the Jinayah law or KUHP, while as a moslem have to defeat his/herself under Jinayat Law.

Qanun Aceh No. 6/ 2014 about Jinaya Law article 5 letter $b$ and $c$ also contradict with the principle of equality before law. It stated that everyone has a same position in front of law without any differences. The result of the implementation of this principle is the essence of law power will be reduced because some of community group is free to choose the law option of their criminal actions, both of the explanation has shown that the good due process of law is unwell reflected under Qanun No. 6/ 2014 of Jinayat Law.

From normative point of view, Jinayah law also has some problem if correlated with Sabang Municipality condition as one of tourism destination in Aceh. In fact, the implementation of Sabang as a tourism destination din't use Jinayah law as a basic rule. Moreover, the reality is the growth of Sabang as tourism area has a contradiction of Jinayah law implementation. This is becomes one of the factorw why the Jinayah Law is more cmplicated to implement in Sabang than any others districts in Aceh. Related to 10 (ten) kind of Jinayah whih regulated in Qanun No. 6/ 2014, Jianayh khalwat is the most Jinayah which is hard to prevent and increase every year.

Based on data from The State of Prosecutor's Office the implementation of Jinayah Khalwat has increased as shown in Table 2:
12 Teguh Prasetyo. (2010). “Hukum Pidana”. Jakarta: Raja Grafindo Persada.P. 29-30.
13 Laden Marpaung. (2012). "Asas-asas Hukum Pidana". Jakarta: Genta Publishing. P.7. 
Table 2. The State of Prosecutor's Office Number of Jinayah Khalwat Perpetrators in Sabang Municipalty Period of June 2015 S/D June 2017

\begin{tabular}{|c|c|c|c|}
\hline Tahun & Kasus Jinayah Khal wat & Sanksi yang diterapkan & Keterangan \\
\hline Juni 2015 & - & - & Tidak ada penindakan \\
\hline Periode 2016 & 4kasus & 4 kasus eksekusi cambuk & Telah dieksekusi \\
\hline Juni 2017 & 20 kasus & 18 kasus eks ekusi denda & 2 kasus berkasnya dikembalikan \\
\hline Total & 24 kasus & 22 kasus di eksekusi & \\
\hline
\end{tabular}

The table shown that, every year the number of Khalwat case has increased, from June to Dece,ber 2015 there no sanction for the perpetartors. Along 2016, the case has increased to be 4 cases and until June 2017, the case increased significantly to be 20 (twenty) cases while 18 (eighteen) cases of it found when the local police and syariah police doing the integration operation at the end of the year.

Based on this explanation, there are some moments (the peak sesaons of tourist) which has a potential period to increase the volume of Jinayah case in Sabang. And for this reason, the officer should increased the awareness and warning in every season of tourism period. The State of Prosecutor's Office as one og the law and justice officer has do some actions started from preventive action to represive action in order to reduce the number of Jinayah Khalwat case. However, it didn't success yet.

Based on the head of The State of Prosecutor's Office opinion, the khalwat perpetrators eradiction couldn't efefctive if its only from the punishment side, without guiding the moral and character of the actors. And also good coordination between the stakeholders becomes an impaortant things to do in Sabang. ${ }^{14}$ One of the contraints is the wrong implementation that given by the Jinayat law officer, for example case No. 01/Nov/ WH/SAB/2016 on behalf of Mirzan Fuadi, ST Lahir di Samalanga, 17 April 1974 No. Identitas: 1172021704740002, Pekerjaan: Karyawan Swasta, Tinggal di Jl. Tgk Abdurrahman Lr. H.M Juned, Lampoh Daya

14 Rohim, Kajari Kota Sabang, Wawancara 23 Agustus 2017

15 Zainal, Warga Gampong Cot Ba'u, Wawancara 12 September 2017
Kec. Jaya Baru Kota Banda Aceh dan Masniati Lahir di Sigli, 1 November 1981 No. Identitas: 117202411820000, Pekerjaan: PNS Dinkes, Tinggal di Jr.Lhok Igeuh Gp. Ujong Kareung Kota Sabang, both of them has found jinayah khalwat on 25 November 2017 in a cafe jalan elak in fornt of panglong kayu (Gampong Cot $\left.\mathrm{Ba}^{\prime} \mathrm{u}\right)$, and saved by peole around 02.30 WIB, then the actors sent to Kantor Satuan Polisi Pamong Praja dan Wilayatul Hisbah for the next ${ }^{15}$

During the process its found that the case has met the requirement of the investigation process, then by the investigator it sets as a suspect. Unfortunately, after set as a suspect, both of them has a right to send their home and the officer didn't used his right as mentioned under Qanun No. 7/ 2013 Tentang Hukum Acara Jinayat artcile 21 verse (2) that stated : for the investigation purpose, the invetsigator has a right to put the suspect in a jail.

Based on sarwadi as an investigator of Satpol PP and $\mathrm{WH}$, there is 3 main consideration of law of this case why there is no jail for the suspect: firstly, the suspect is cooperative, secondly, Mirzan Fuadi, ST is a political actor in Sabang and Masniati is a government official, and thirdly there is no jail room in Satpol PP and WH office. ${ }^{16}$ As a result, one of the suspect (Mirzan Fuadi,. ST) has run away from Sabang and din't find out until now. The law cosequency is the

16 Sarwadi PPNS Satuan Polisi Pamong Praja dan Wilayatul Hisbah Kota Sabang, Wawancara 5 September 2017 
case couldn't send to Mahkamah Syaeriah Sabang. ${ }^{17}$

Based on the experience, a direct detention has been done for 18 suspect of Khalwat at the en of 2016. Sarwadi as the investigator of Satpol PP and $\mathrm{WH}$ has his own initiative to detent all the perpetratotrs in Jail of Satpol PP WH Aceh. This is not only becqause of the lack of jajil room but also lack of investigators in Sabang. Until now, Satpol PP and WH Sabang only has 1 investigator and it couldn't enough to do 18 cases of Khalwat ${ }^{18}$

Khalwat's problems in Sabang is very coomplicated. For better implementation, there are five things that should be done in Sabang for law effectiveness, such as:

1. The law factor itself;

2. The officer factor who run the law;

3. Facility factor to support the implementation of law;

4. Community factor, the environment where the law has been implemented;

5. Cultural factore as a resutl of creativity and sense of human art. ${ }^{19}$

Based on these factors, there are three has been identified as a contratints in the implementation process, firstly is form the law factor itself/ regulation in the crminal ascpet still weal based on the attorney officer (because it didn't cummulative/ sum of the main sanction), as a result if didn't give the detterent effect for the actors, on the other hand jinayah law is not a product of law which didn't give protection for children who has a problems with law and the law maker is false in order to implement article 5 letter b and c of Qanun Aceh No. 6/2014 about Jinayah Law as personality principle because there is no correlation between verse in that article with personality principle definition, even the use of that artcile has made denial of legality principle and the principle of equality before the law. Second contraint is the law

17 Yunadi, Ajun Fungsional Kejaksaan Negeri Kota Sabang, Wawancara 23 Agustus 2017

18 Sarwadi, PPNS Satuan Polisi Pamong Praja dan Wilayatul Hisbah Kota Sabang, Wawancara 5 September 2017 officer factor who has an authority to run the law or the level of quality of human resource which become one of the weaknesses on the effectivenees of law implementation in Sbaang. For example, the process of unexactly law decision which resulted in unclear some of cases and also another contraints due to the number of investigators where Sabang only has 1 (one) investogator which affected on the progress of the adminitrasyion process. Thirdly, facility factor, currently, Satpol PP and WH in Sabang didn't has a jail room which result in every person who do the khlawt have to send to banda Aceh.

\section{Conclusion}

The implementation of Qanun No. 6/2014 about Jinayah Law didn't run effectively in Sabang, because the law itself hjas some weaknesses in terms of uqubat/ criminal punishments that didn't well regulated to give detterant effect for the perpetartors of jarimah, the differentiation of law subjects based on the religion has shown that material law didn't give justice for Indoensia citizen and jinayah law also didn;t give protection for childrens who has problems with law where there is no mechanism in Jinayah law related to whip punishment for childern in fornt of public. Beside the weakness of regulation, the quality and quantity of human sources especially for the investigators heed to be increased to avoid the mistaken in decision process and also to accelerate the process of khalwat adminitration. Lastly, the facility factor becomes the worst one as currently there is no jail room to put the suspect of Jarimah Khalwat.

\section{Acknowledgments}

Thanks to Dr. Dahlan as the first mentor in research writing and Dr. Suhaimi as the second mentor in this study who has provided direction and input for the writing of the journal goes well.

19 Soerjono Soekanto. (2008). "Faktor-Faktor yang Mempengaruhi Penegakan Hukum".Jakarta: PT. Raja Grafindo Persada.Jakarta. P. 8 


\section{References}

Qanun No.6 Tahun 2014 tentang Hukum Jinayat.

Al Yasa'Abubakar. Sekilas Syariat Islam di Aceh. Dinas Syariat Islam Propinsi Aceh.

Al Yasa Abubakar. (2009). Walayatul Hisbah : Polisi Pamong Praja Dengan kewenangan Khusus di Aceh, Dinas Syariat Islam, Banda Aceh.

Bernard L. Tanya, Yoan N. Simanjuntak, Markus Y. Hage. (2013). Teori Hukum. Semarang: Genta Publishing.

Dinas Syariat Islam Aceh. (2015). Qanun Aceh Nomor 6 Tahun 2014 Tentang Hukum Jinayat, Banda Aceh.

Dinas Syariat Islam Nanggroe Aceh Darussala. (2005). Himpunan UndangUndang,Keputusan

Presiden,Peraturan Daerah/Qanun, Instruksi Gubernur, dan Edaran Gubernur, CV. Hardyan,Banda Aceh.

Kaelan. (2004). Pendidikan Pancasila. Yogyakarta: Paradigma

Leden Marpaung. (2009). Asas-Teori-Praktek Hukum Pidana. Jakarta: Sinar Grafika, Jakart.

Peter Mahmud Marzuki, Penelitian Hukum, Jakarta: Kencana Prenada Media Grup.

Soejono Soekanto. (1984). Pengantar Penelitian Hukum.UI-PRESS.

Teguh Prasetyo. (2010). Hukum Pidana. Jakarta: Raja Grafindo Persada.

\section{Peraturan Perundang-undangan}

Undang-Undang Dasar Negara Kesatuan Republik Indonesia Tahun 1945.

Undang-Undang No. 44 Tahun 1999 tentang Pelaksanaan Keistimewaan Propinsi Daerah Istimewa Aceh.

Undang-Undang No. 18 Tahun 2001 tentang Otonomi Khusus Bagi Propinsi Daerah Istimewa Aceh Sebagai Nanggroe Aceh Darussalam.

Undang-Undang No. 11 Tahun 2006 tentang Pemerintah Aceh.

Undang-Undang No.24 Tahun 2004 tentang Kekuasaan Kehakiman

Undang-Undang No.16 Tahun 2004 tentang Kejaksaan

Undang-Undang No.35 Tahun 2014 tentang Perlindungan Anak 